\title{
IN THE MUSEUM
}

\section{A J Ryan (University of KwaZulu-Natal, Durban)}

With the help of a generous donation from Miss Joan Law, the Museum of Classical Archaeology has recently acquired a small Roman bronze ithyphallic herm of Pan holding a pedum or shepherd's crook (Figs. $1 \& 2$ ) from the $1^{\text {st }}$ or $2^{\text {nd }}$ century CE. ${ }^{1}$ The bottom-most part of the base has broken off, but the object is otherwise in excellent condition with slight patination. The base is rectangular up to the waist. The buttocks are not sculpted but simply indicated by a single incised line. From the waist up the details, such as the musculature, face and hair, are very finely rendered. The figure arches his back and raises his right hand to his forehead while his left hand supports a pedum. He is bearded with short unkempt hair and visible horns.

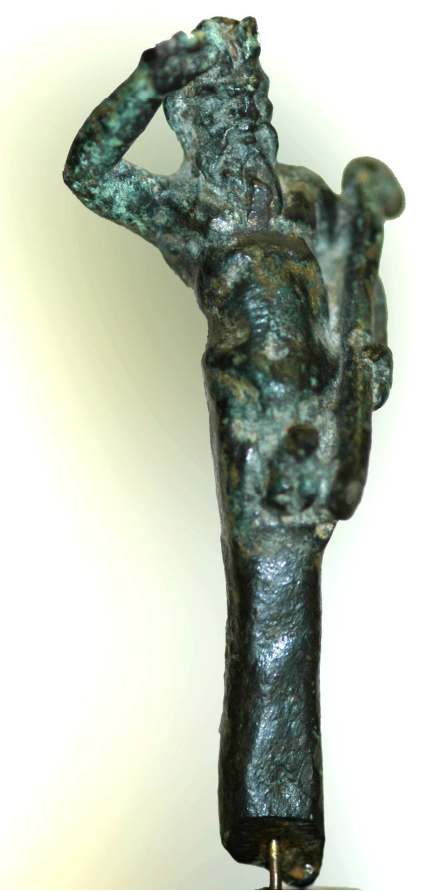

Fig. 1. Durban 2008.54

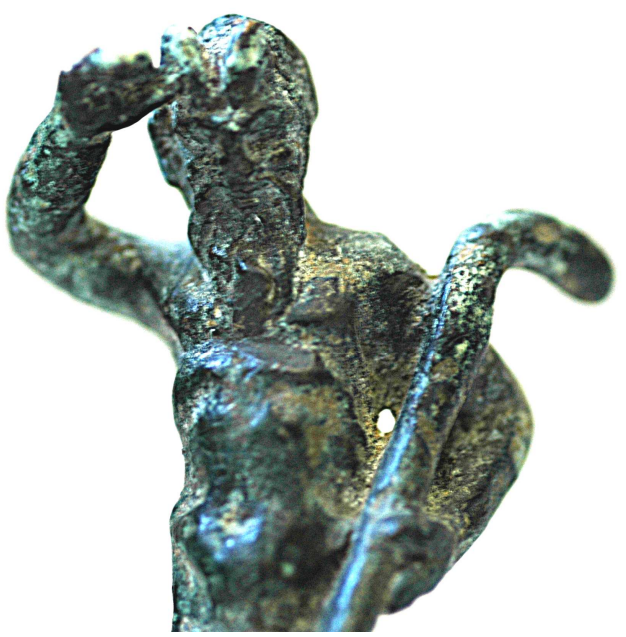

Fig. 2. Detail

The Greeks and Romans used a number of methods to fashion bronze sculptures. For small pieces such as ours, the lost wax method was preferred. ${ }^{2}$ By this method, a model of the sculpture was first made out of wax. This could either have been solid, or it could have been sculpted over a core (made from a material with suitably high melting temperature) with little pins called chaplets sticking out through the wax. The model was then covered in two sets of clay coating. The first set comprised a single layer of fine clay that preserved the details of the sculpture, and the second set

1 Durban 2008.54 . The figure is $54 \mathrm{~mm}$ high, the arms are $2.4 \mathrm{~mm}$ (right) and $2.6 \mathrm{~mm}$ (left) from the shoulder to the tip of the hands.

$2 \quad$ Noble 1975 provides a more detailed description of the process. 
comprised a number of layers of coarse cay to make the mold more robust. The mold was then dried and heated resulting both in the clay being hardened and the wax melting out. After this, the metal was poured into the cavity left by the molten wax. If a solid model had been used, the empty cavity would fill entirely with bronze, and a solid statue like our example would be produced. If, on the other hand, the wax had been sculpted around a core, then when the wax melted out, the core remained in place, separated from the body of the mold by the chaplets (illustrated in Fig. 3). This resulted in a hollow statue.

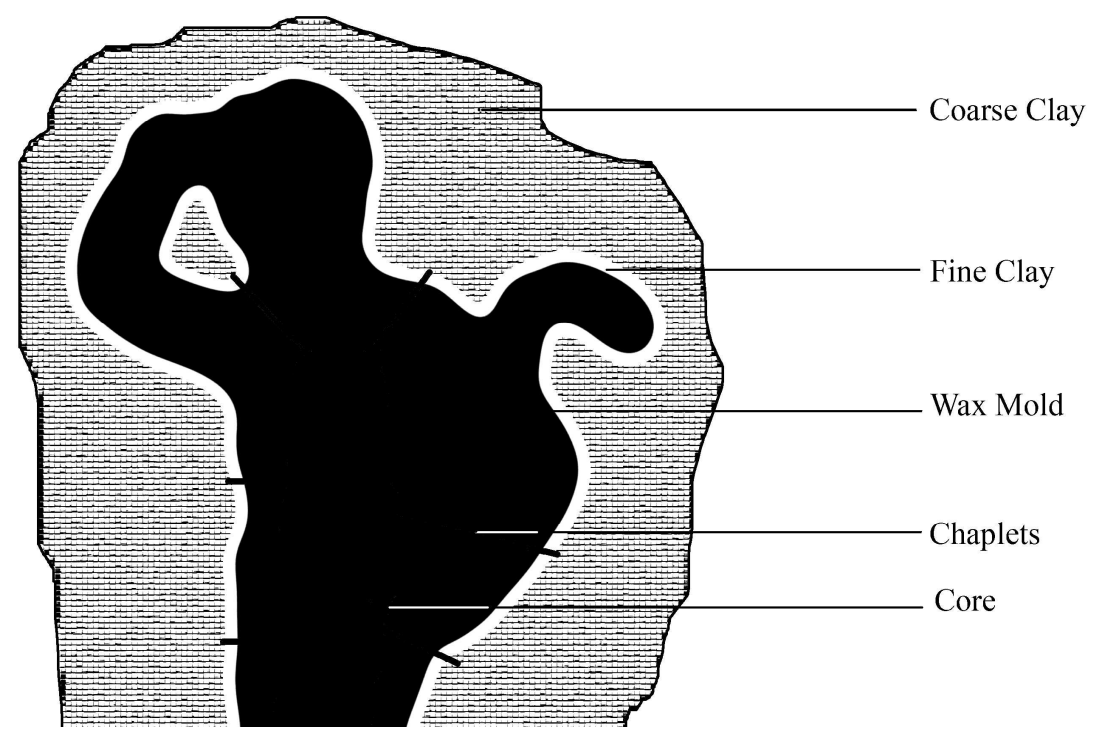

Fig. 3. The lost wax method

The lost wax process did not easily admit copies to be made since the wax original was melted and the cast had to be broken in order to remove the bronze. After this, the bronze was polished and decorated with incisions. These could be achieved either by using a tiny hammer and chisel, or by engraving.

The herm, or herma (pl. hermai), was a type of statue that usually took the form of a rectangular base surmounted by a sculpted or cast head, with complete (often ithyphallic) genitalia about half-way up the base. Herms usually had no arms (the Durban figure is a counterexample), and could appear in a variety of sizes, although the smaller objects were more common in the Hellenistic and Roman periods than in the archaic and Classical. ${ }^{3}$ The term hermai was originally used in early Greece to denote piles of stones that were placed at the sides of roads as boundary markers and milestones. At some stage during the archaic period herms came to be associated with the god Hermes and the herm became standardized as an ithyphallic rectangular stone or wooden base with the head of Hermes on top. The form is attributed by some to Hipparchus, who set up numerous herms, inscribed with

3 Mattusch 1996:169. 
inspirational maxims, along the roads of Attica as milestones. ${ }^{4}$ Herodotus (Hdt. 2.51), on the other hand, claims that this form of the worship of Hermes had Pelasgian origins.

The nature of the relationship between the truly multi-faceted ${ }^{5}$ god Hermes and the herm form is not well understood and is the subject of some debate. Robinson argued that herms were so called after Hermes in his guise as a god of cross-roads and a transgressor of boundaries. ${ }^{6}$ A similar theory is that the boundary markers, conflated with archetypal notions of the trickster and the messenger god, gave birth to the god Hermes in the Greek popular imagination. Burkert maintains that the erect phallus, being a primordial symbol of male territorial demarcation, is a further indicator of the god's association with boundaries. ${ }^{7}$ Jost refutes this position pointing out that Hermes' name appears on Mycenaean documents and must be earlier than the stone markers. Instead she argues that the connection between Hermes and the herms lies in former's guise as a god of abundance ${ }^{8}$ who brought good fortune to both merchants and shepherds. While Burket believes the main functions of the herms were mainly as territorial demarcations, most scholars believe their function became largely apotropaic towards the end of the archaic period. The Athenians were probably responsible for popularizing the use of the herm for this purpose. Large marble and bronze herms were often placed in homes, in the countryside, at cross-roads and in doorways for protection. Despite the strong association with the god Hermes, during the Classical period the herm started to be used as simply another form of portraiture and admitted other gods being represented this way. This portraiture was not limited to gods, but herms of political figures and athletes have also been found. The herm became very popular amongst the Romans, particularly in the form of little statuettes like ours. The most common subjects of Roman herms were gods and deities such as Silenus $^{9}$ and Priapus. ${ }^{10}$

Our object is of the latter variety, and represents the pastoral god Pan. Originally Pan was an Arcadian shepherd god, but he came to be worshiped widely in both Greece and Rome. According to Herodotus (Hdt. 6.104) the cult of Pan was introduced to Athens by Pheidippides after the god appeared to him on his way from Marathon to Athens and offered his assistance. In return the Athenians honoured the god and built him a shrine once they had dealt with the economic consequences of the war. Most mythological accounts claim Pan to be the son of Hermes. The Homeric Hymn to Pan makes him the son of Hermes and Dryope (Hymn. Hom. Pan 34), while

4 Plat. Hipp 228d. Paus. 1.24.3 also claims the Athenians to be the inventors of the 'limbless' herm type.

5 Amongst other things, Hermes is associated with merchants, travelers, messengers, guests, hospitality, wit, abundance, boundaries, cross-roads, and more. A complete list of attributes is found in Sibert 1990:285-289 and Chittenden's seminal paper (1947) is still a useful source.

6 Robinson 1955: 22.

7 Burkert 1977:156 regards the phallus as a primitive territorial marker. Elsewhere (Burkert 1979:40), he describes how some breeds of monkeys guard the troop's territory by standing at outposts facing outwards and displaying their erect organs. Jost 1996.

For example Bowdoin College Museum of Art 1923.38; Mitten \& Doeringer 1968: no 192. Such as Ostia Inv. 3543; Calza 1915:171; fig 43. 
Herodotus makes him the son of Hermes and Penelope (Hdt. 2.145). Hermes is not the only father attested in the mythological record, and even Odysseus is suggested by an obscure Hellenistic riddle. ${ }^{11}$ Nevertheless it was Hermes with whom the Greeks associated Pan most closely, and together with whom he was often worshipped. Perhaps for etymological reasons Pan also appears in later literature as a god of everything. But in cult he remained a pastoral deity and this is reflected in his iconography. The Homeric hymn to Pan lists three of these attributes: he has a goat's legs and horns (Hymn. Hom. Pan. 19.2) and he wears a pelt (19.24). The Durban example, being a herm, does not have any legs, and has a bare torso, but his horns can be seen clearly in plate 1.b. Other pastoral iconography includes the syrinx or reedflute and the pedum (crook). On the Durban piece, he holds the pedum in his left arm. The Durban example also illustrates a less common iconographical attribute of Pan as aposkopeuon 'keeping watch', with his hand over his brow so as to block the sun as he watches his flock from afar. Although this particular form does appear in statuettes, ${ }^{12}$ it is more common on coins and in paintings. ${ }^{13}$

Small Roman statuettes of bronze and other metals are abundant and offer us a little insight into the private religious lives of ordinary citizens. Apart from herms, there are many other types of statuettes that have a religious function. The typical Roman house would have at least one lararium - a shrine often located in the wall of the atrium or near the hearth - in which statuettes of the household gods would be tended, sometimes by the sacrifice of cakes and confections, as well other foods. The ordinary Roman was quite superstitious and statuettes could also serve as votive offerings at the shrines of a deity whose aid or blessing was sought. Alternatively many bronze statuettes were decorative, sometimes attached to household furniture or tableware. Herms were popularly used for this purpose. It is not clear what purpose the Durban herm served, and since the base is broken off, it is not certain whether it was part of a larger piece or not. Whatever the case may be, it is a very good example of its type with unusually fine detail and makes a welcome addition to the Museum's collection of later Roman statuary.

\section{BIBLIOGRAPHY}

Boardman, J 1997. LIMC VII s.v. Pan.

Burkert, W 1977. Greek Religion. Cambridge MA: Harvard University Press.

Burkert, W 1979. Structure and history in Greek mythology and ritual Berkeley: University of California Press.

Calza, G 1915. Expressions of art in a Roman commercial city: Ostia. JRS 5:165-72.

Chittenden, J 1947. The master of animals. Hesperia 16: 89-114.

11 Theoc $[$ Syrinx $] .1$.

12 For example, the Staatliche Museen in Berlin (misc. 8624) has an example of a bronze goatheaded Pan in such a pose; Sekunda 2002: 37.

13 A famous painting by Antiphilus renders either Pan or a satyr in this manner according to Plin. $H N$ 35.138, and numerous examples of Pan in this pose exist in red-figure vase-paintings, a selection of which appear in Boardman 1997: no 40-47. 
Edmonds, J (trans.) 1960. The Greek Bucolic Poets. Cambridge, MA: Harvard University Press.

[LIMC] Ackerman, HC, Gisler, LR et al (eds.) 1981-1997 Lexicon iconographicum mythologiae Classicae Zurich: Artemis Verlag.

Evelyn-White, H G (trans.) 1977. Hesiod, the Homeric hymns and Homerica Cambridge MA: Harvard University Press.

$\left[O C D^{3}\right]$ Hornblower, S \& Spawforth, A (eds.) 1996. The Oxford Classical Dictionary, $3^{\text {rd }}$ edition. Oxford: Oxford University Press.

Lamb, W R M (trans.) 1964. Plato with an English translation. Cambridge MA: Harvard University Press.

Jones, W H S (trans.) 1933. Pausanius: Description of Greece volume I. Cambridge MA: Harvard University Press.

Jost, M 1996. $O C D^{3}$ s.v Hermes.

Mattusch, C C 1996. Classical Bronzes: The Art and Craft of Greek and Roman Statuary. Ithaca NY: Cornell University Press.

Mitten, D G \& Doeringer, S F (eds.) 1967. Master Bronzes from the Classical World. Cambridge, MA: Fogg Art Museum.

Noble, J V 1975. The wax of the lost wax process. JHS 79:368-369.

Robinson, D M 1955. Unpublished sculpture in the Robinson collection. AJA 59: 19-29.

Sekunda, N. 2002. Marathon 490 BC: The First Persian Invasion of Greece. Oxford: Osprey Publishing.

Siebert, G. 1990. LIMC V s.v. Hermes. 